\title{
Gill lesions and mortality in seawater pen-reared Atlantic salmon Salmo salar associated with a dense bloom of Skeletonema costatum and Thalassiosira species
}

\author{
M. L. Kent ${ }^{1}$, J. N. C. Whyte ${ }^{1}$, C. LaTrace ${ }^{2}$ \\ ' Biological Sciences Branch, Department of Fisheries and Oceans, Pacific Biological Station, Nanaimo, British Columbia, Canada V9R 5K6 \\ ${ }^{2}$ Moore-Clarke, Ltd, \#303 909 Island Hwy, Campbell River, British Columbia, Canada V9W 2C2
}

\begin{abstract}
Mortality and gill lesions in Atlantic salmon Salmo salar reared in a seawater netpen in British Columbia, Canada, were associated with a dense bloom of diatoms containing predominantly Skeletonema costatum, Thalassiosira aestivalis and $T$. rotula. Other diatoms, present as minor components of the bloom, included Thalassionema nitzschioides, Coscinodiscus sp. and Pseudonitzschia sp. Gills of moribund and dead fish exhibited excessive mucus production. Histological examination revealed necrosis of the gill epithelium and edema at the base of secondary lamellae. The edematous spaces contained an inflammatory infiltrate. The mechanism of gill damage was not determined, but was likely due to physical irritation by the algae. None of these diatoms have previously been reported to cause disease in fish.
\end{abstract}

KEY WORDS: Gill disease - Salmo salar - Skeletonema Thalassiosira

Algal blooms have caused mortality in wild and farmed fishes in coastal waters throughout the world (Gaines \& Taylor 1986, Shumway 1990, Kent \& Fournie 1992). There are 4 known general mechanisms by which algal blooms may kill fish: physical damage to the gills caused by the spines of diatoms, asphyxiation caused by oxygen depletion, gas-bubble trauma due to extreme oxygen saturation from algal photosynthesis, and direct chemical toxicity caused by ichthyotoxins (Black et àl. 1991).

In the Pacific Northwest of North America, blooms of the flagellate Heterosigma carterae (= akashiwo) and 3 diatoms, Chaetoceros convolutus, C. concavicornis, and a Corethron sp., have been associated with mortality in pen-reared salmon (Gaines \& Taylor 1986, Rensel et al. 1989, Speare et al. 1989, Horner et al. 1990, Black et al. 1991. Taylor 1993). These diatoms cause gill lesions by physical irritation to the epithelium, resulting in excessive mucus production which leads to asphyxiation
(Bell 1961, Farrington 1988, Bruno et al. 1989, Rensel 1992, Yang \& Albright 1992). Irritation is caused by the brittle setae and multicelled chains of these diatoms. As these features are common to many species of diatoms, it is possible that intense blooms of other diatom species could damage fish gills.

In addition to occasional blooms of the recognized pathogenic algae, heavy blooms of diatoms such as Skeletonema and Thalassiosira species often occur at farms in British Columbia, Canada, without any apparent deleterious effects. Fish farmers and fish health specialists, therefore, usually considered these common algae to be nonpathogenic and have not been concerned when they occurred in high densities. Nevertheless, Bruno et al. (1989) reported that species of some other common algae, such as the silicoflagellate Distephanus speculum and the diatom Chaetoceros debile, may damage the gills of pen-reared salmon.

We report here on gill damage and mortality of penreared Atlantic salmon Salmo salar associated with a dense mixed diatom bloom containing mainly Skeletonema spp. and large chain-forming Thalassiosira spp.

Materials and methods. One of us (C.L.) visited an Atlantic salmon Salmo salar netpen farm near Quadra Island, British Columbia, following a report by the farm owner of a dense phytoplankton bloom and increased fish mortality. The kidneys of 3 moribund fish were cultured for pathogenic bacteria using tryptic soy agar and sheep blood agar. Gills and visceral organs from 5 moribund fish were preserved in Davidson's fixative (Humason 1979) and processed for light histology. Samples of the water during the height of the bloom and $3 \mathrm{~d}$ later were examined for phytoplankton.

Results. A dense algal bloom occurred on 4 April 1994 at a netpen farm near Quadra Island. The bloom 
lasted $14 \mathrm{~d}$. A dramatic increase in mortality in Atlantic salmon post-smolts at the farm (introduced to seawater 1 mo earlier) was noted by the farmer during the first day of the bloom and continued for 1 wk. A $4 \%$ (approximately 16000 fish) mortality was attributed to the bloom.

Water samples taken during the bloom contained predominantly the straight-chain cylindrical Skeletonema costatum (Figs. 1 \& 2). The other major biomass of the diatom bloom consisted of chains of the large $(20$ to $50 \mu \mathrm{m}$ ) quadrangular cells of Thalassiosira aestivalis (Fig. 2) and the discoid diatom, T. rotula. Other diatoms observed in fewer numbers were Thalassionema nitzschioides, Coscinodiscus sp., and Pseudonitzschia sp. Very few Chatoceros spp. were observed.

Affected fish were hyperemic at the base of the pectoral fins and along the ventral surface. Internal examination revealed no gross pathological changes. Many moribund fish exhibited excessive mucus secretion on the surface of the gills.

Histological examination revealed gill lesions in the moribund fish (Figs. 3 to 6 ). The gills exhibited congestion of the central venous sinus at the base of the primary lamellae and diffuse edema at the base of the secondary lamellae (Fig 3). A mixed inflammatory infiltrate occurred within the edematous spaces, comprised primarily of phagocytes. Many of these phago- cytes were replete with necrotic cellular debris and refractive granular material (Fig. 5). This material stained purple with red granules with periodic acid Schiff's (PAS) and was not acid-fast, and was thus consistent with lipofuscin.

Prominent, multifocal necrosis of the gill epithelium was observed in 1 fish (Figs. 4 \& 6). Mucus-containing diatom fragments and sloughed, necrotic epithelial cells were observed between the lamellae. The other fish exhibited these changes, but to a milder extent. Internal organs appeared normal, except that 1 fish exhibited mild, diffuse necrosis of the epithelium in the pyloric caeca. No bacteria were isolated from the kidneys of the affected fish.

Discussion. The histological changes suggested that the morbidity was due to gili lesions. No other pathogens (e.g. bacteria, protozoa) were observed in the affected gills, and lesions were most severe when directly associated with accumulations of algae. Therefore, the best explanation for the gill lesions and the concurrent mortality was the occurrence of excessive densities of Skeletonema costatum and Thalassiosira spp. Members of these genera are common in coastal waters of British Columbia, and have not previously been recognized as potential causes of gill lesions.

The lesions described here are similar to those reported for the Chaetoceros and Corethron species, in
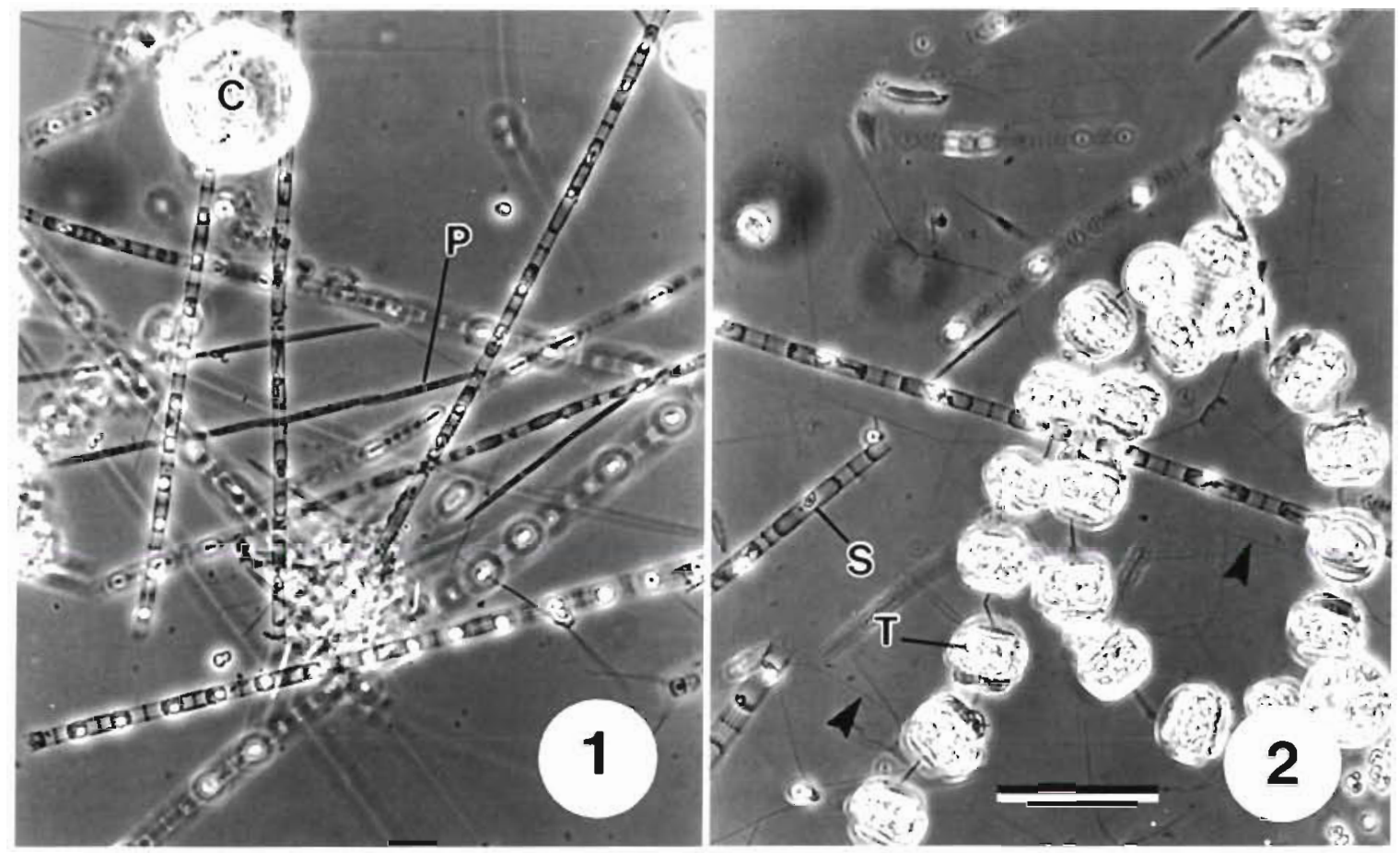

Figs. 1 \& 2. Diatoms from a plankton bloom associated with mortality of pen-reared Atlantic salmon Salmo salar. S: Skeletonema costatum; T: Thalassiosira aestivalis; arrowheads: setae of $T$ aestivalis; $\mathrm{P}$ : Pseudonitzschia sp.; C: Coscinodiscus sp. Scale bar $=50 \mu \mathrm{m}$ 


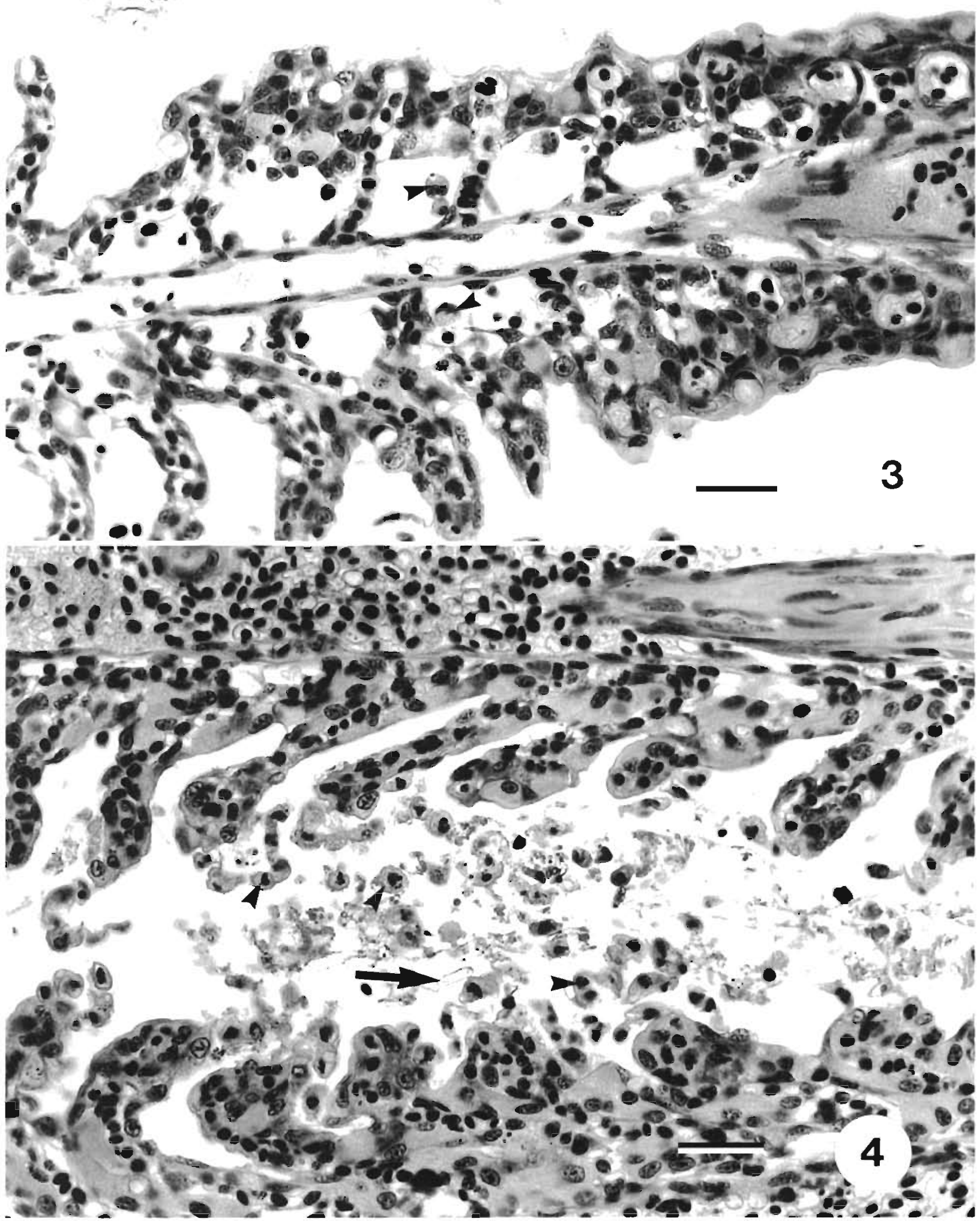

Figs. 3 \& 4 . Salmo salar. Gill lesions associated with algal bloom. Hematoxylin and eosin, scale bar $=50 \mu \mathrm{m}$. Fig. 3 . Edema and inflammation of gills associated with diatom bloom. Arrowheads: inflammatory cells in edematous spaces. Fig. 4. Necrosis of gill epithelium associated with diatom bloom. Arrowheads: necrotic epithelial cells; arrow: diatom 


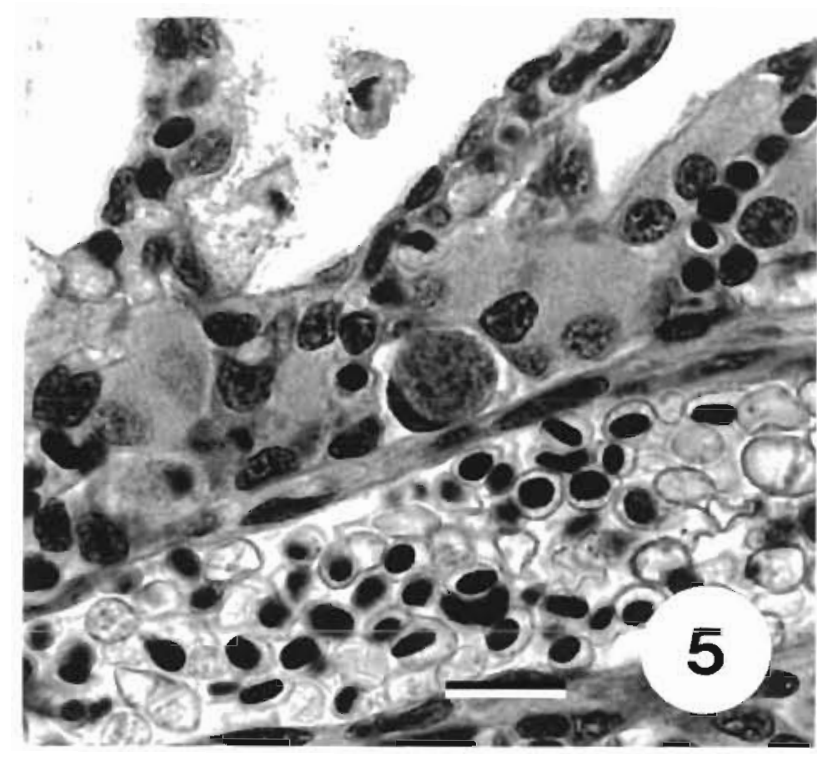

Fig. 5. Salmo salar. Phagocyte containing lipofuscin debris in gills. Hematoxylin and eosin, scale bar $=20 \mu \mathrm{m}$

that epithelial damage is associated with accumulations of algal cells at the gill surface (Speare et al. 1989, Rensel 1992, Yang \& Albright 1992). However, the lesions reported here differ from those of previous reports in that edema was marked, with infiltration of ceroid-laden macrophages, and epithelial hyperplasia was absent in the present study. Post-mortem separation of the gill epithelium may occur if gills are not preserved shortly after death (Speare \& Ferguson 1989), and may be confused with ante-mortem lamellar

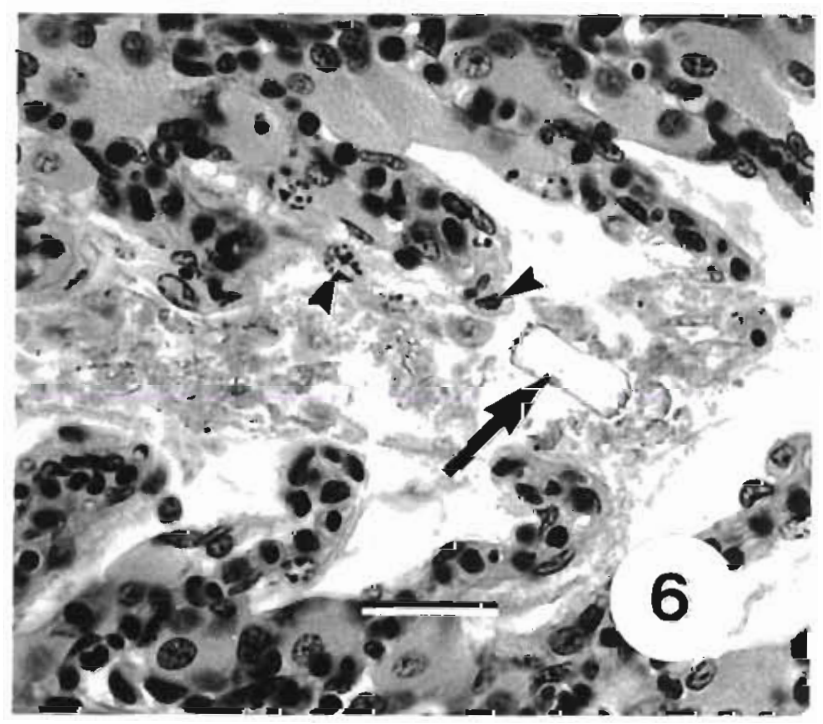

Fig. 6. Salmo salar. Diatom (arrow) entrapped in mucus with refractile debris. Note associated necrosis of the gill epithelium (arrowheads). Scale bar $=20 \mu \mathrm{m}$ epithelial lifting and other edematous changes. This was unlikely the case in our study because gills were preserved immediately after death and inflammatory cells were consistently observed within the edematous spaces.

Chaetoceros species cause gill disease due to mechanical damage to the epithelium (Rensel 1992, Yang \& Albright 1992), and this probably occurred in the present study because the lesions were most severe in areas where algal cells were entrapped in the overlying mucus. Although Thalassiosira spp. and Skeletonema spp. do not possess barbs on their setae (as seen in pathogenic Chaetoceros species), they have long siliceous setae that may damage the gill surface. Nevertheless, we cannot exclude the possibility that a toxin was aiso involved in the disease.

This study presents the first report that associates gill disease with members of the genera Thalassiosira and Skeletonema, and indicates that certain algae considered to be nonpathogenic may cause gill disease when present in high densities. More information on the precise density of algae and determination of the alga(e) in the mixed bloom that actually caused the gill damage is needed.

Acknowledgements. We thank Dr D. J. Speare for helpful suggestions and Dr T P. T. Evelyn for manuscript review.

\section{LITERATURE CITED}

Bell GR (1961) Penetration of spines from a marine diatom into the gill tissues of lingcod (Ophiodon elongatus). Nature 192:279-280

Black EA, Whyte JNC, Bagshaw JW, Ginther NG (1991) The effects of Heterosigma akashiwo on juvenile Oncorhynchus tshawytscha and its implications for fish culture. J appl Ichthyol 7:168-175

Bruno DW, Dear G, Seaton DD (1989) Mortality associated with phytoplankton blooms among farmed Atlantic salmon, Salmo salar L., in Scotland. Aquaculture 78: $217-222$

Farrington CW (1988) Mortality and pathology of juvenile chinook salmon (Oncorhynchus tshawytscha) and chum salmon (Oncorhynchus keta) exposed to cultures of the marine diatom Chaetoceros convolutus. MSc thesis, University of Alaska, Juneau

Games G, Taylor FJR (1986) A mariculturist's guide to potentially harmful marine phytoplankton of the Pacific coast of North America. Marine Resources Section, Fisheries Branch, British Columbia Ministry of the Environment, Information Rep 10

Horner RA, Postel SR, Rensel JE (1990) Noxious phytoplankton blooms in western Washington waters. A review. In Granéli E, Sundström B, Edler L, Anderson DM (eds) Toxic marine phytoplankton. Elsevier, New York, p 171-176

Humason GL (1979) Animal tissue techniques. WH Freeman, San Francisco

Kent ML. Fournie JW (1992) Importance of marne fish diseases - an overview. In: Fournie JW, Couch JA (eds) The pathobiology of marine and estuarine organisms. CRC 
Press, Boca Raton, p 1-24

Rensel JE (1992) Harmful effects of the marine diatom Chaetoceros concavicornis on Atlantic salmon (Salmo salar). $\mathrm{PhD}$ thesis, University of Washington, Seattle

Rensel JE, Horner R, Postel JR (1989) Effects of phytoplankton blooms on salmon aquaculture in Puget Sound, Washington: initial research. Northwest Environ J 5:53-69

Shumway SE (1990) A review of the effects of algal blooms on shellfish and aquaculture. J World Aquacult Soc 21: 65-104

Speare DJ, Brackett J, Ferguson HW (1989) Sequential pathology of the gills of coho salmon with a combined

Responsible Subject Editor: W. Körting, Hannover, Germany diatom and microsporidian gill infection. Can Vet $\mathrm{J} 30$ 571-575

Speare DJ, Ferguson HW (1989) Fixation artifacts in rainbow trout (Salmo gairdneri) gills: a morphometric evaluation Can J Fish Aquat Sci 46:780-785

Taylor FJR (1993) Current problems with harmful phytoplankton blooms in British Columbia. In: Smayda TJ, Shimizu Y (eds) Toxic phytoplankton blooms in the sea. Elsevier Science Publishers, New York, p 699-703

Yang CZ. Albright LJ (1992) Effects of the harmful diatom Chaetoceros concavicornis on respiration of rainbow trout Oncorhynchus mykiss. Dis aquat Org 14:105-114

Manuscript first received: August 22, 1994

Revised version accepted: January 5, 1995 